\title{
The Association of FTO SNP rs9939609 with Weight Gain at University
}

\author{
Susanne F. Meisel ${ }^{a} \quad$ Rebecca J. Beeken ${ }^{a} \quad$ Cornelia H.M. van Jaarsveld ${ }^{b}$ \\ Jane Wardle ${ }^{a}$ \\ ${ }^{a}$ Cancer Research UK Health Behaviour Research Centre, Department of Epidemiology and \\ Public Health, University College London, UK; ${ }^{b}$ Department of Primary Care and Public \\ Health Sciences, King's College London, London, UK
}

\author{
Key Words \\ FTO $\cdot$ Genetics · Weight gain · Genetic test feedback · Young adult · University
}

\begin{abstract}
Aim: We tested the hypothesis that the obesity-associated FTO SNP rs9939609 would be associated with clinically significant weight gain ( $\geq 5 \%$ of initial body weight) in the first year of university; a time identified as high risk for weight gain. Methods: We collected anthropometric data from university students ( $n=1,411$, mean age: $22.4 \pm 2.5$ years, $49.1 \%$ male) at the beginning and end of the academic year. DNA was analysed for FTO rs9939609. Associations of FTO genotype with BMI at baseline were analysed using ANCOVA, and with risk of 5\% weight gain over follow-up with logistic regression; both analyses adjusting for age and sex. The alpha level was reduced to 0.0125 to account for multiple testing. Results: Using an additive model, FTO status was not associated with higher BMI at baseline $\left(22.2 \mathrm{vs} .21 .9 \mathrm{~kg} / \mathrm{m}^{2}\right.$, $p=0.059)$. Dropout was high but unrelated to genotype. Among the $310(21.9 \%)$ completing follow-up, those with AT genotypes had twice the odds of $\geq 5 \%$ weight gain compared with TTs $(\mathrm{OR}=2.05,95 \% \mathrm{CI}=1.05-4.01, \mathrm{p}=0.036)$, but this was no longer significant after Bonferroni correction. There was a trend for AA carriers for $\geq 5 \%$ weight gain compared with TT carriers $(p=0.089)$, but sample size was small. Conclusion: This study provides nominal evidence for the genetic susceptibility hypothesis, but findings need to be replicated.
\end{abstract}

(c) 2015 S. Karger GmbH, Freiburg

\section{Introduction}

The behavioural susceptibility model of obesity proposes that individuals at higher genetic risk are more likely to overeat - and therefore gain weight - than their lower risk counterparts in situations of abundant food availability [1,2]. This model is consistent with 
Meisel et al.: The Association of FTO SNP rs9939609 with Weight Gain at University

the changing population distribution of weight seen over the last few decades as the environment has become more 'obesogenic'; with weights at the lower end of the distribution staying fairly stable, while weights at the upper end have shown dramatic increases [3].

Multiple genes are associated with variation in weight in the population [4-6], with the strongest body of evidence for FTO, the first gene identified to be associated with 'common' obesity [7-9]. The SNP rs9939609, located on the first intron of the FTO gene, belongs to a cluster of 10 SNPs which have been associated with BMI early on [10].

Individuals who are homozygous for the higher-risk 'A' allele of SNP rs9939609 are on average $3 \mathrm{~kg}$ heavier, and have a 20\% higher lifetime risk of becoming obese, than the lower risk 'TT' homozygotes [7-9]. FTO has been shown to be expressed in the hypothalamus and adjacent nuclei associated with feeding behaviour and food reward [11,12], with gene expression modulated by food availability [13]. However, the mechanism whereby FTO exerts it effects is yet to be fully understood. The presence of FTO in the cell nucleus [11], its structure and resemblance to homologues involved in nucleic acid repair or modification, and the preferential binding to single-stranded RNA over double-stranded DNA of the FTO protein, suggested early on that it may be concerned with nucleic acid demethylation; which was recently confirmed [14]. Emerging evidence further suggests that the intronic SNP rs9939609 may influence BMI by increasing expression of FTO itself [15], or by forming long-range functional connections which increase the expression of other neighbouring genes such as IRX3 [16] and RPGRIP1L [17].

In human studies, the A allele of FTO SNP rs9939609 has been associated with lower satiety responses and a higher propensity to eat when palatable food is supplied $[1,18,19]$; although evidence for overall increased energy intake is mixed [20-23]. With respect to weight loss, which could be used as a reverse longitudinal phenotype, FTO appears to have little influence on the success of lifestyle interventions aimed at weight loss [24-27]. However, to our knowledge, no study has specifically investigated whether FTO genotype moderates weight change following a move to a more obesogenic environment.

The transition from high school to university has been identified as a high-risk period for weight gain $[28,29]$. It has been informally dubbed the 'Freshman 15', although most evidence indicates that average weight gain is closer to $5 \mathrm{lbs}[30,31]$, and may be even lower outside of the USA [29]. However, within this mean change, there is considerable individual variability, and to date there have been few pointers to the determinants of risk [30].

The present study used the 'freshman' context to test the genetic moderation hypothesis. Clinical studies assume a 5\% weight loss beneficial [32]. However, by the same token, a 5\% weight gain could therefore be considered clinically significant with respect to future health problems. We hypothesised that individuals carrying at least one higher-risk allele (AT, AA) would be more likely to experience a clinically significant weight gain ( $\geq 5 \%$ of initial weight) over the first year at university.

\section{Material and Methods}

\section{Participants and Procedures}

New students from a large UK university were recruited at the start of three consecutive academic years (October 2010, 2011, 2012). Follow-up anthropometric data were collected in the last week of May of each academic year. All interested individuals within the university aged between 18 and 30 years who were able to give informed consent were eligible.

The study was advertised by email, posters on campus, in halls of residence, and at the 'Welcome Fayre'; inviting students to take part in a study on genetic influences on weight gain. Interested participants were invited to come to the 'data collection stand' during the 2 nd week of term. Here, a researcher explained the 
Meisel et al.: The Association of FTO SNP rs9939609 with Weight Gain at University

project in more detail, gave out information sheets and offered the opportunity to ask questions. Those willing to take part gave written consent. Ethical approval for the study was granted by the University College London Ethics Committee for non-NHS research (study no. 2471/002).

Sample Size

A power calculation conducted a priori using G*Power (version 3.1; Heinrich Heine University Düsseldorf, Germany) showed that a total sample size of $n=148$ would be sufficient to detect a small effect $(d=0.25)$ on $5 \%$ weight gain with $95 \%$ power at the $5 \%$ significance level anticipating attrition of about $60 \%$ which is common in samples involving students [33].

\section{Measures}

Demographic information included age and sex. Anthropometric data were collected at study enrolment and at follow-up about 8 months later. Participants were asked to remove shoes, socks and outdoor clothes for weighing. Weight was measured to the nearest tenth of a kilogram with the TANITA scale (TBF-300 MA, Sindlfingen, Germany). Height was measured to the nearest centimetre using the Leicester Height Measure (Marsden Group, UK). BMI was calculated from weight and height $\left(\mathrm{kg} / \mathrm{m}^{2}\right.$ ), and classified according to World Health Organization cut-off points (underweight/normal weight $<25.0 \mathrm{~kg} / \mathrm{m}^{2}$, overweight $\geq 25.0$ to $<30.0$ $\mathrm{kg} / \mathrm{m}^{2}$, obese $\geq 30 \mathrm{~kg} / \mathrm{m}^{2}$ ) [17]. Participants could opt to receive a printout of their anthropometric results, and all chose to do so.

A saliva sample for DNA extraction was collected after enrolment by asking the participant to place some sugar on their tongue to stimulate saliva flow and then spit into a plastic tube to generate 1.5-2 ml of saliva. Saliva samples were coded with a unique identifier number immediately after collection so that they were anonymous but could be linked to the anthropometric data. DNA was isolated from saliva and analysed at The Institute of Metabolic Science, Cambridge, UK, as previously published [2].

Statistical Analyses

Statistical analyses were carried out using the Statistical Package for Social Sciences (SPSS) version 20.0 (Chicago, IL, USA). Chi-square tests were performed to assess whether genotype frequencies were in HardyWeinberg equilibrium.

We used an additive model to explore the associations of FTO genotype with weight gain (TT vs. AT vs. AA) in all analyses. However, we also explored associations of genotype and weight gain in a dominant model (TT vs. AT/AA), in line with some previous studies [34, 35], and because the small sample size at follow-up meant that there were only very few participants with the AA genotype. The association of FTO genotype status with BMI at baseline was determined with Analysis of Covariance (ANCOVA), with age and sex as covariates. For the purpose of all analyses, age was dichotomized into 'younger' (18-20 years) and 'older' (age 21 years and over) because the strength of the FTO association with BMI has been shown to differ by age [36]. Bonferroni corrections were used to correct for multiple testing, and the alpha level to indicate significance was reduced to $\alpha=0.0125$.

Weight change, both absolute (kg) and relative (percentage), was calculated for each participant. For binary analyses, we examined the proportion who gained $\geq 5 \%$ of their starting weight. The association between FTO gene status and 5\% weight gain over follow-up period was investigated using binary logistic regression analyses adjusting for age (dichotomized) and sex.

\section{Results}

\section{Participant Characteristics}

In total, 1,518 students volunteered to take part. 107 (7.0\%) had to be excluded for the following reasons: genotype could not be determined $(5.8 \%, n=89)$, missing anthropometric data $(0.9 \%, \mathrm{n}=13)$ and no assigned ID so genotype data could not be matched to anthropometric data $(0.04 \%, \mathrm{n}=5)$. The final baseline sample therefore consisted of 1,411 participants. Follow-up data were collected from 310 participants (21.9\%). Anthropometric and demographic characteristics of those who were followed up were similar at baseline to the full sample (table 1). 
Meisel et al.: The Association of FTO SNP rs9939609 with Weight Gain at University

Table 1. Participant characteristics at baseline and follow-up

\begin{tabular}{|c|c|c|c|}
\hline Participant characteristics & $\begin{array}{l}\text { Baseline sample } \\
(\mathrm{N}=1,411)\end{array}$ & $\begin{array}{l}\text { Follow-up sample } \\
(\mathrm{N}=310)\end{array}$ & $\mathrm{p}$ value \\
\hline \multicolumn{4}{|l|}{ Baseline } \\
\hline Mean height, m (SD) & $1.70(0.09)$ & $1.71(0.09)$ & 0.865 \\
\hline Mean weight, kg (SD) & $64.2(12.0)$ & $63.2(2.6)$ & 0.190 \\
\hline Mean BMI, kg/m² (SD) & $22.0(3.0)$ & $21.6(2.8)$ & 0.061 \\
\hline Underweight/normal weight, n (\%) & $1,217(86.3)$ & $280(90.3)$ & 0.062 \\
\hline Overweight/obese, n (\%) & $194(13.7)$ & $30(9.7)$ & \\
\hline \multicolumn{4}{|l|}{ Sex } \\
\hline Male, n (\%) & $693(49.1)$ & $148(47.7)$ & 0.707 \\
\hline Female, n (\%) & $718(50.9)$ & $162(52.3)$ & \\
\hline Mean age, years (SD) & $20.4(2.5)$ & $20.3(2.6)$ & 0.570 \\
\hline $18-20$ years, $n(\%)$ & $883(62.6)$ & $198(63.9)$ & 0.697 \\
\hline 21-30 years, $\mathrm{n}(\%)$ & $528(37.4)$ & $112(36.1)$ & \\
\hline \multicolumn{4}{|l|}{ FTO status, n (\%) } \\
\hline TT & $599(42.5)$ & $133(42.9)$ & \\
\hline AT & $631(44.7)$ & $137(44.2)$ & 0.986 \\
\hline AA & $181(12.8)$ & $40(12.9)$ & \\
\hline \multicolumn{4}{|l|}{ Follow-up } \\
\hline Mean BMI, $\mathrm{kg} / \mathrm{m}^{2}(\mathrm{SD})$ & - & $21.7(2.9)$ & \\
\hline Underweight/normal weight, \% (n) & - & $276(89.0)$ & \\
\hline Overweight/obese, \% (n) & - & $34(11.0)$ & \\
\hline Mean weight, kg (SD) & - & $63.8(11.6)$ & \\
\hline Mean weight change, kg (SD) & & $0.54(3.36)$ & \\
\hline \multicolumn{4}{|l|}{$\geq 5 \%$ weight gain, $\%$ (n) } \\
\hline No & - & $255(82.3)$ & \\
\hline Yes & - & $55(17.7)$ & \\
\hline
\end{tabular}

Table 2. Participant characteristics by gender

\begin{tabular}{|c|c|c|c|}
\hline Participant characteristics & Male & Female & $\begin{array}{l}\mathrm{p} \text { value } \\
\text { (nominal) }\end{array}$ \\
\hline \multicolumn{4}{|l|}{ Baseline } \\
\hline Mean BMI, kg/m² (SD) & $22.7(2.5)$ & $21.2(2.9)$ & $<0.001$ \\
\hline Underweight/normal weight, \% (n) & $573(82.7)$ & $644(89.7)$ & $<0.001$ \\
\hline Overweight/obese, \% (n) & $120(17.3)$ & $74(10.3)$ & \\
\hline Mean age, years (SD) & $20.3(2.4)$ & $20.5(2.5)$ & 0.129 \\
\hline $18-20$ years, $n(\%)$ & 450 (64.9) & $433(60.3)$ & 0.072 \\
\hline $21-30$ years, $\mathrm{n}(\%)$ & $243(35.1)$ & $285(39.7)$ & \\
\hline \multicolumn{4}{|l|}{ FTO status, n (\%) } \\
\hline $\mathrm{TT}$ & $290(41.8)$ & $309(43.0)$ & 0.648 \\
\hline AT & $318(45.9)$ & $313(43.6)$ & \\
\hline AA & $85(12.3)$ & $96(13.4)$ & \\
\hline \multicolumn{4}{|l|}{ Follow-up } \\
\hline Mean BMI, $\mathrm{kg} / \mathrm{m}^{2}(\mathrm{SD})$ & $22.5(2.8)$ & $22.7(2.8)$ & $<0.001$ \\
\hline Underweight/normal weight, n (\%) & $129(87.2)$ & $147(90.7)$ & 0.316 \\
\hline Overweight/obese, n (\%) & $19(12.8)$ & $15(9.3)$ & \\
\hline \multicolumn{4}{|l|}{$\geq 5 \%$ weight gain, $n(\%)$} \\
\hline No & $118(79.7)$ & $137(84.6)$ & 0.265 \\
\hline Yes & $30(20.3)$ & $25(15.4)$ & \\
\hline
\end{tabular}


Meisel et al.: The Association of FTO SNP rs9939609 with Weight Gain at University

Table 3. Participant characteristics by FTO genotype

\begin{tabular}{|c|c|c|c|c|}
\hline Participant characteristics & TT genotype & AT genotype & AA genotype & $\begin{array}{l}\mathrm{p} \text { value } \\
\text { (nominal) }\end{array}$ \\
\hline \multicolumn{5}{|l|}{ Baseline } \\
\hline Mean BMI, kg/m² (SD) & $21.7(2.9)$ & $22.1(3.0)$ & $22.0(2.8)$ & 0.082 \\
\hline Underweight/normal weight, n (\%) & $528(88.1)$ & $529(83.8)$ & $160(88.4)$ & 0.060 \\
\hline Overweight/obese, n (\%) & $71(11.9)$ & $102(16.2)$ & $21(11.6)$ & \\
\hline \multicolumn{5}{|l|}{ Sex } \\
\hline Male n (\%) & $290(41.8)$ & $318(45.9)$ & $85(12.3)$ & 0.648 \\
\hline Female n (\%) & $309(43.0)$ & $313(43.6)$ & $96(13.4)$ & \\
\hline Mean age, years (SD)* & $20.54(2.6)^{\mathrm{a}}$ & $20.40(2.5)^{\mathrm{a}}$ & $20.0(2.2)^{\mathrm{b}}$ & 0.027 \\
\hline $18-20$ years, $\mathrm{n}(\%)$ & $363(41.1)$ & $394(44.6)$ & $126(14.3)$ & 0.089 \\
\hline $21-30$ years, $\mathrm{n}(\%)$ & $236(44.7)$ & 237 (44.9) & $55(10.4)$ & \\
\hline \multicolumn{5}{|l|}{ Follow-up } \\
\hline Mean BMI, $\mathrm{kg} / \mathrm{m}^{2}(\mathrm{SD})$ & $21.7(2.8)$ & $22.0(2.9)$ & $21.9(3.4)$ & 0.707 \\
\hline Underweight/normal weight, n (\%) & $121(91.0)$ & $119(86.9)$ & $36(90.0)$ & 0.545 \\
\hline Overweight/obese, n (\%) & $12(9.0)$ & $18(13.1)$ & $4(10.0)$ & \\
\hline \multicolumn{5}{|l|}{$\geq 5 \%$ weight gain, $n(\%)$} \\
\hline No & $117(88.0)$ & $107(78.1)$ & $31(77.5)$ & 0.074 \\
\hline Yes & $16(12.0)$ & $30(21.9)$ & $9(22.5)$ & \\
\hline
\end{tabular}

*Means that do not share superscripts differ by $\mathrm{p}<0.05$.

At baseline, students' mean weight was $64.2 \mathrm{~kg}$ ( $\mathrm{SD}=12.0$ ), height was $1.70 \mathrm{~m}$ (SD = 0.09 ) and BMI was $22.0 \mathrm{~kg} / \mathrm{m}^{2}$ (SD = 3.0). Only a very small proportion $(6.4 \% ; \mathrm{n}=91)$ of participants were classified as underweight $\left(B M I<18.5 \mathrm{~kg} / \mathrm{m}^{2}\right)$; so they were grouped with normal-weight participants $(79.8 \%, \mathrm{n}=1,126)$. Less than a quarter of the sample $(13.7 \%, \mathrm{n}=194)$ were classified as overweight/obese. Mean age was 20.4 years at baseline ( $\mathrm{SD}=2.5$ years), with $62.6 \%(\mathrm{n}=883)$ of the sample in the $18-20$ age group and $37.4 \%$ $(n=528)$ being older. We also present descriptive data for males and females separately (table 2).

Baseline Differences in BMI by FTO Genotype

FTO was in Hardy-Weinberg equilibrium at baseline $\left(\chi^{2}(2)=0.54, p=0.462\right)$ and at follow-up $\left(\chi^{2}(2)=0.28, p=0.868\right)$.

Unadjusted differences in BMI by FTO genotype are presented in table 3. Using the additive model, the association between FTO genotype and BMI was not significant in adjusted analyses $(\mathrm{p}=0.059)$; although there was a trend for those carrying the TT genotype to have a lower BMI than those carrying the AT genotype $\left(21.8 \mathrm{~kg} / \mathrm{m}^{2}\right.$ vs. $22.2 \mathrm{~kg} / \mathrm{m}^{2}$; Bonferronicorrected $\mathrm{p}=0.078$ ). Age was significantly associated with BMI, with 'older' students having a higher BMI than 'younger' students $\left(22.5 \mathrm{~kg} / \mathrm{m}^{2}\right.$ vs. $21.6 \mathrm{~kg} / \mathrm{m}^{2}, \mathrm{~F}(1,1,406)=30.55$; Bonferroni-corrected $\mathrm{p}<0.001$ ). Sex was also significantly associated with BMI, with men having a higher BMI than women $\left(22.8 \mathrm{~kg} / \mathrm{m}^{2}\right.$ vs. $21.4 \mathrm{~kg} / \mathrm{m}^{2}, \mathrm{~F}(1,1,406)=99.9$; Bonferronicorrected $\mathrm{p}<0.001$ ).

Assuming a dominant model, individuals carrying at least one A allele had a higher BMI than those with the lower-risk TT genotype; adjusting for age and sex $\left(22.2 \mathrm{vs} .21 .9 \mathrm{~kg} / \mathrm{m}^{2}, \mathrm{~F}\right.$ $(1,1407)=5.66 ; p=0.017)$. However, this finding remained no longer significant after applying the Bonferroni-corrected alpha level. The significant effects of age and gender were replicated (data not shown). 
Meisel et al.: The Association of FTO SNP rs9939609 with Weight Gain at University

Table 4. Multivariable predictors of $5 \%$ weight gain

\begin{tabular}{llll}
\hline Variable & OR & $95 \% \mathrm{CI}$ & $\begin{array}{l}\text { p value } \\
\text { (nominal) }\end{array}$ \\
\hline $\begin{array}{l}\text { FTO status } \\
\text { TT }\end{array}$ & 1 & & \\
AT & 2.05 & $1.05-4.01$ & 0.036 \\
AA & 2.24 & $0.88-5.70$ & 0.089 \\
Age & & & \\
$\quad$ 21-30 years & 1 & & \\
$\quad$ 18-20 years & 2.91 & $1.39-6.11$ & 0.005 \\
$\begin{array}{l}\text { Sex } \quad \text { Female } \\
\quad \text { Male }\end{array}$ & 1 & & \\
\hline & 1.28 & $0.69-2.32$ & 0.428 \\
\hline
\end{tabular}

Weight Gain over Follow-Up by FTO Genotype

Attrition was high, with only $21.9 \%(n=310)$ of the sample returning for follow-up weighing.

Weight change over the 8-month study period in those returning for follow-up was modest on average, but there was considerable variation (mean $+0.54 \mathrm{~kg}, \mathrm{SD}=3.36 \mathrm{~kg}$, range -12.60 to $14.40 \mathrm{~kg})$. Just over half the students had gained weight $(51.3 \%, \mathrm{n}=159)$, with $45.9 \%$ losing weight, and the remainder staying precisely stable. However, almost one in five of the total sample $(17.7 \% ; n=55)$ had gained at least $5 \%$ of their initial body weight.

Using the additive model and adjusting for age and sex, FTO status was significantly associated with 5\% weight gain at follow-up, with individuals carrying the AT genotype being about twice as likely to have gained at least $5 \%$ of their starting weight than participants carrying the TT genotype (OR 2.05, 95\% CI 1.05-4.01; p =0.036), and a trend for AA carriers to be more likely to have gained at least $5 \%$ of their starting weight than TT carriers (OR 2.24, 95\% CI 0.88-5.70; $\mathrm{p}=0.089$ ). However, after applying Bonferroni correction, the former finding was no longer significant (table 3). Age was also a significant predictor of weight gain in the dominant model, with those between 18 and 20 years being more likely to have gained at least $5 \%$ of their starting weight than older participants using Bonferroni-corrected alpha levels (OR 2.91, 95\% CI 1.39-6.11; p = 0.005). Sex was not a significant predictor of weight gain $(\mathrm{p}=0.428)$ (table 4$)$.

Using the dominant model, FTO status was also associated with a weight gain $\geq 5 \%$ in unadjusted analyses ( $\mathrm{p}=0.022$ ), but, again, this finding remained no longer significant in adjusted analyses using the Bonferroni-corrected alpha level (OR 2.09, 95\% CI 1.10-3.98; p $=0.024$ ). Effects of age were replicated (data not shown).

\section{Discussion}

This is the first study to investigate the moderating effect of FTO gene status on weight gain over the medium term which is associated with a move into an environment that often provides greater freedom around eating behaviour than life within the parental home and abundant eating opportunities. Albeit only nominal and requiring replication in sufficiently large samples, the results showed that individuals with the higher-risk variants of the FTO gene were significantly more likely to experience significant weight gain ( $\geq 5 \%$ of their initial body weight) than those with the lower-risk genotype, with similar effects using additive and dominant models. 
Weight gain overall was modest ( $\sim 0.5 \mathrm{~kg})$; well below the anecdotal 'freshman 15 ', or the $5 \mathrm{lb}$ observed in some US samples [28,37]. However, younger students were more likely to gain $\geq 5 \%$ of their body weight than older students, suggesting that those who had recently transitioned from school to university were at greater risk than those who had either been at other universities or had taken on some other young adult role.

Although previous studies have investigated determinants of weight gain in student samples and found alcohol consumption, stress and high consumption of junk food to be significant predictors of weight gain [14,37-40], none have taken the genetic perspective. Similarly, although some studies have investigated the effect of FTO in individuals attempting weight loss [24-27], none have focused on cohorts with low motivation to prevent weight gain. Evidence that FTO operates in part at least through effects on satiety responsiveness and food reward $[2,12,41]$ suggests scope to evaluate interactions between genotype and environments with a highly palatable food supply and abundant eating opportunities; in particular, since emerging evidence suggests that genetics may also influence food choice [42].

The study had many limitations. Participant retention proved a challenge: despite personalized email reminders and small incentives to return for follow-up weighing, nearly $80 \%$ of the sample was lost to follow-up. This may have been, in part, due to the timing of follow-up weighing being scheduled at the end of the academic year when students were busy with exam preparations. Secondly, although it was presumed that all students had increased exposure to the obesogenic environment of university life, some students may have chosen to limit their exposure, for example by avoiding socialising in environments in which eating and drinking was involved. Some may have maintained the traditional diet of their home country (UCL has a high proportion of international students), and others may have taken advantage of opportunities to be physically active as part of university sports clubs; all of which would have limited the impact of any genetic predisposition to weight gain. Unfortunately, the current study did not assess whether students joined any sports clubs, or any other behavioural mediators, which limits the conclusions that can be drawn, but these could be investigated in future research. Thirdly, relatively few overweight and obese individuals took part in the study although the university in which the study was carried out has high academic standard and therefore may have had a lower prevalence of obesity given the established link between obesity and lower educational attainment (e.g. $[43,44])$. It is therefore likely that the current findings provide a conservative estimate of the effects of FTO on weight gain in first-year university students. Since these results provided only nominal evidence for an association of FTO genotype with $>5 \%$ weight gain, these findings will need to be replicated in sufficiently large samples.

\section{Conclusion}

Despite its limitations, this study provides nominal evidence that carriers of the higherrisk alleles of the FTO gene were more likely to gain significant amounts of weight as they moved into an environment known to carry an obesogenic risk than participants with the lower-risk TT genotype. Weight gain prevention programmes might benefit from including genetic information to raise awareness of personal risk of weight gain associated with move to an obesogenic environment.

\section{Acknowledgements}

This research was supported by a grant from Cancer Research UK (C1418/A10843). 
Meisel et al.: The Association of FTO SNP rs9939609 with Weight Gain at University

\section{Disclosure Statement}

The authors have no conflict of interest to declare.

\section{References}

1 Farooqi IS, O’Rahilly S: Genetics of obesity in humans. Endocr Rev 2006;27:710-718.

12 Wardle J, Llewellyn C, Sanderson S, Plomin R: The FTO gene and measured food intake in children. Int J Obes (Lond) 2008;33:42-45.

-3 Wardle J, Boniface D: Changes in the distributions of body mass index and waist circumference in English adults, 1993/1994 to 2002/2003. Int J Obes (Lond) 2008, 32:527-532.

-4 Willer CJ, Speliotes EK, Loos RJ, Li S, Lindgren CM, Heid IM, Berndt SI, Elliott AL, Jackson AU, Lamina C, Lettre G, Lim N, Lyon HN, McCarroll SA, Papadakis K, Qi L, Randall JC, Roccasecca RM, Sanna S, Scheet P, Weedon MN, Wheeler E, Zhao JH, Jacobs LC, Prokopenko I, Soranzo N, Tanaka T, Timpson NJ, Almgren P, Bennett A: Six new loci associated with body mass index highlight a neuronal influence on body weight regulation. Nat Genet 2009;41:25-34.

5 Speliotes EK, Willer CJ, Berndt SI, Monda KL, Thorleifsson G, Jackson AU, Lango AH, Lindgren CM, LuanJ, Magi R, Randall JC, Vedantam S, Winkler TW, Qi L, Workalemahu T, Heid IM, Steinthorsdottir V, Stringham HM, Weedon MN, Wheeler E, Wood AR, Ferreira T, Weyant RJ, Segre AV, Estrada K, Liang L, Nemesh J, Park JH, Gustafsson S, Kilpelainen TO: Association analyses of 249,796 individuals reveal 18 new loci associated with body mass index. Nat Genet 2010;42:937-948.

6 Lu Y, Loos R: Obesity genomics: assessing the transferability of susceptibility loci across diverse populations. Genome Med 2013;5:55.

-7 Frayling TM, Timpson NJ, Weedon MN, Zeggini E, Freathy RM, Lindgren CM, Perry JR, Elliott KS, Lango H, Rayner NW, Shields B, Harries LW, Barrett JC, Ellard S, Groves CJ, Knight B, Patch AM, Ness AR, Ebrahim S, Lawlor DA, Ring SM, Ben-Shlomo Y, Jarvelin MR, Sovio U, Bennett AJ, Melzer D, Ferrucci L, Loos RJ, Barroso I, Wareham NJ, Karpe F, Owen KR, Cardon LR, Walker M, Hitman GA, Palmer CN, Doney AS, Morris AD, Smith GD, Hattersley AT, McCarthy MI: A common variant in the FTO gene is associated with body mass index and predisposes to childhood and adult obesity. Science 2007;316:889-894.

8 Dina C, Meyre D, Gallina S, Durand E, Korner A, Jacobson P, Carlsson LM, Kiess W, Vatin V, Lecoeur C, Delplanque J, Vaillant E, Pattou F, Ruiz J, Weill J, Levy-Marchal C, Horber F, Potoczna N, Hercberg S, Le Stunff C, Bougneres P, Kovacs P, Marre M, Balkau B, Cauchi S, Chevre JC, Froguel P: Variation in FTO contributes to childhood obesity and severe adult obesity. Nature Genet 2007;39:724-726.

-9 Scuteri A, Sanna S, Chen WM, Uda M, Albai G, Strait J, Najjar S, Nagaraja R, Orru M, Usala G, Dei M, Lai S, Maschio A, Busonero F, Mulas A, Ehret GB, Fink AA, Weder AB, Cooper RS, Galan P, Chakravarti A, Schlessinger D, Cao A, Lakatta E, Abecasis GR: Genome-wide association scan shows genetic variants in the FTO gene are associated with obesity-related traits. PLoS Genet 2007;3:115.

10 Speakman JR: The 'Fat Mass and Obesity Related' (FTO) gene: mechanisms of impact on obesity and energy balance. Curr Obes Rep 2015;4:73-91.

11 Gerken T, Girard CA, Tung YC, Webby CJ, Saudek V, Hewitson KS, Yeo GS, McDonough MA, Cunliffe S, McNeill LA, Galvanovskis J, Rorsman P, Robins P, Prieur X, Coll AP, Ma M, Jovanovic Z, Farooqi IS, Sedgwick B, Barroso I, Lindahl T, Ponting CP, Ashcroft FM, O'Rahilly S, Schofield CJ: The obesity-associated FTO gene encodes a 2-oxoglutarate-dependent nucleic acid demethylase. Science 2007;318:1469-1472.

12 Karra E, O’Daly OG, Choudhury AI, Yousseif A, Millership S, Neary MT, Scott WR, Chandarana K, Manning S, Hess ME: A link between FTO, ghrelin, and impaired brain food-cue responsivity. J Clin Invest 2013;123:35393351.

13 Fredriksson R, Hägglund M, Olszewski PK, Stephansson H, Jacobsson JA, Olsaweska AM, Levine AS, Lindblom J, Schiöth HB: The obesity gene, FTO, is of ancient origin, up-regulated during food deprivation and expressed in neurons of feeding-related nuclei of the brain. Endocrinology 2008;149:2062-2071.

14 Jia G, Fu Y, Zhao X, Dai Q, Zheng G, Yang Y, Yi C, Lindahl T, Pan T, Yang YG, He C: N6-Methyladenosine in nuclear RNA is a major substrate of the obesity-associated FTO. Nat Chem Biol 2011;7:885-887.

15 Berulava T, Horsthemke B: The obesity-associated SNPs in intron 1 of the FTO gene affect primary transcript levels. Eur J Hum Genet 2010;18:1054-1056.

-16 Smemo S, Tena JJ, Kim KH, Gamazon ER, Sakabe NJ, Gomez-Marin C, Aneas I, Credidio FL, Sobreira DR, Wasserman NF, Lee JH, Puviindran V, Tam D, Shen M, Son JE, Vakili NA, Sung HK, Naranjo S, Acemel RD, Manzanares M, Nagy A, Cox NJ, Hui CC, Gomez-Skarmeta JL, Nobrega MA: Obesity-associated variants within FTO form long-range functional connections with IRX3. Nature 2014;507:371-375.

-17 Stratigopoulos G, Martin Carli JF, O’Day DR, Wang L, Leduc CA, Lanzano P, Chung WK, Rosenbaum M, Egli D, Doherty DA, Leibel RL: Hypomorphism for RPGRIP1L, a ciliary gene vicinal to the fto locus, causes increased adiposity in mice. Cell Metab 2014;19:767-779.

18 Cecil JE, Tavendale R, Watt P, Hetherington MM, Palmer CN: An obesity-associated FTO gene variant and increased energy intake in children. N Engl J Med 2008;359:2558-2566. 
19 Wardle J, Carnell S, Haworth CM, Farooqi IS, O’Rahilly S, Plomin R: Obesity associated genetic variation in FTO is associated with diminished satiety. J Clin Endocrinol Metab 2008;93:3640-3643.

20 Bauer F, Elbers CC, Adan RA, Loos RJ, Onland-Moret NC, Grobbee DE, van Vliet-Ostaptchouk JV, Wijmenga C, van der Schouw YT: Obesity genes identified in genome-wide association studies are associated with adiposity measures and potentially with nutrient-specific food preference. Am J Clin Nutr 2009;90:951-959.

21 Speakman JR, Rance KA, Johnstone AM: Polymorphisms of the FTO gene are associated with variation in energy intake, but not energy expenditure. Obesity (Silver Spring) 2008;16:1961-1965.

22 Hasselbalch A Laengquist L, Christiansen L, Heitmann BL, Kyvik KO, Soerensen TI: A variant in the fat mass and obesity-associated gene (FTO) and variants near the melanocortin-4 receptor gene (MC4R) do not influence dietary intake. Nutr J 2010;140:831-834.

23 Holzapfel C, Grallert H, Huth C, Wahl S, Fischer B, Daering A: Genes and lifestyle factors in obesity: results from 12462 subjects from MONICA/KORA. Int J Obes (Lond) 2010;34:1538-1545.

24 Haupt A, Thamer C, Machann J, Kirchhoff K, Stefan N, Tschritter O, Machicao F, Schick F, Häring H, Fritsche A: Impact of variation in the FTO gene on whole body fat distribution, ectopic fat, and weight loss. Obesity (Silver Spring) 2008;16:1969-1972.

25 Lappalainen TJ, Tolppanen AM, Kolehmainen M, Schwab U, Lindström J, Tuomilehto J, Pulkkinen L, Eriksson JG, Laakso M, Gylling H: The common variant in the FTO gene did not modify the effect of lifestyle changes on body weight: the Finnish Diabetes Prevention Study. Obesity (Silver Spring) 2009;17:832-836.

26 Mitchell JA, Church TS, Rankinen T, Earnest CP, Sui X, Blair SN: FTO genotype and the weight loss benefits of moderate intensity exercise. Obesity (Silver Spring) 2010;18:641-643.

27 Matsuo T, Nakata Y, Murotake Y, Hotta K, Tanaka K: Effects of FTO genotype on weight loss and metabolic risk factors in response to calorie restriction among Japanese women. Obesity (Silver Spring) 2012;20:11221126.

28 Gropper SS, Simmons KP, Gaines A, Drawdy K, Saunders D, Ulrich P, Connell LJ: The freshman 15: a closer look. J Am Coll Health 2009;58:223-231.

29 Serlachius A, Hamer M, Wardle J: Stress and weight change in university students in the United Kingdom. Physiol Behav 2007;92:548-553.

30 Mihalopoulos NL, Auinger P, Klein JD: The freshman 15: is it real? J Am Coll Health 2008;56:531-533.

31 Hoffman DJ, Policastro P, Quick V, Lee SK: Changes in body weight and fat mass of men and women in the first year of college: a study of the 'Freshman 15'. J Am Coll Health 2006;55:41-45.

32 Goldstein DJ: Beneficial health effects of modest weight loss. Int J Obes Relat Metab Disord 1992;16:397-415.

-33 Laska MN, Pelletier JE, Larson NI, Story M: Interventions for weight gain prevention during the transition to young adulthood: a review of the literature. J Adolesc Health 2012;50:324-333.

-34 Dougkas A, Yaqoob P, Givens DI, Reynolds CK, Minihane AM: The impact of obesity-related SNP on appetite and energy intake. Br J Nutr 2013;110:1151-1156.

- 35 den Hoed M, Westerterp-Plantenga MS, Bouwman FG, Mariman EC, Westerterp KR: Postprandial responses in hunger and satiety are associated with the rs9939609 single nucleotide polymorphism in FTO. Am J Clin Nutr 2009;90:1426-1432.

-36 Hardy R, Wills AK, Wong A, Elks CE, Wareham NJ, Loos RJ, Kuh D, Ong KK: Life course variations in the associations between FTO and MC4R gene variants and body size. Hum Mol Genet 2010;19:545-552.

-37 Cluskey M, Grobe D: College weight gain and behavior transitions: male and female differences. J Am Diet Assoc 2009;109:325-329.

-38 Economos CD, Hildebrandt L, Hyatt RR: College freshman stress and weight change: differences by gender. Am J Health Behav 2008;32:16-25.

39 Levitsky DA, Halbmaier CA, Mrdjenovic G: The freshman weight gain: a model for the study of the epidemic of obesity. Int J Obes (Lond) 2004;28:1435-1442.

40 Nikolaou CK, Hankey CR, Lean MEJ: Weight changes in young adults: a mixed-methods study. Int J Obes (Lond) 2015;39:508-513.

41 Llewellyn CH, van Jaarsveld CH, Plomin R, Fisher A, Wardle J: Inherited behavioral susceptibility to adiposity in infancy: a multivariate genetic analysis of appetite and weight in the Gemini birth cohort. Am J Clin Nutr 2012;95:633-639.

42 Qi Q, Chu AY, Kang JH, Huang J, Rose LM, Jensen MK, Liang L, Curhan GC, Pasquale LR, Wiggs JL, De V, I, Chan AT, Choi HK, Tamimi RM, Ridker PM, Hunter DJ, Willett WC, Rimm EB, Chasman DI, Hu FB, Qi L: Fried food consumption, genetic risk, and body mass index: gene-diet interaction analysis in three US cohort studies. BMJ 2014;348:g1610.

43 Wardle J, Waller J, Jarvis MJ: Sex differences in the association of socioeconomic status with obesity. Am J Public Health 2002;92:1299-1304.

44 Leigh JP, Fries JF, Hubert HB: Gender and race differences in the correlation between body mass and education in the 1971-1975 NHANES I. J Epidemiol Commun Health 1992;46:191-196. 